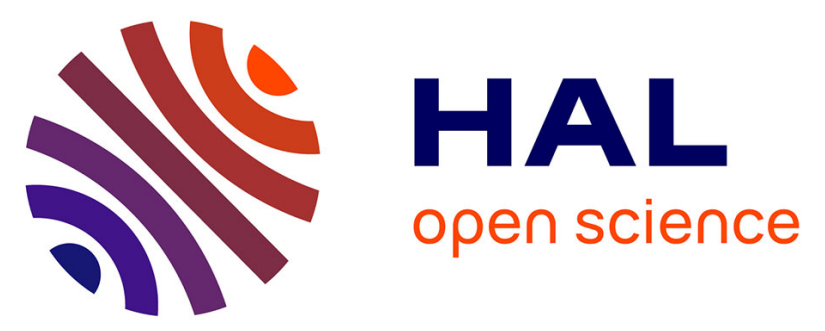

\title{
Contrasting resistance and resilience to extreme drought and late spring frost in five major European tree species
} Yann Vitasse, Alessandra Bottero, Maxime Cailleret, Christof Bigler, Patrick Fonti, Arthur Gessler, Mathieu Levesque, Brigitte Rohner, Pascale Weber, Andreas Rigling, et al.

\section{To cite this version:}

Yann Vitasse, Alessandra Bottero, Maxime Cailleret, Christof Bigler, Patrick Fonti, et al.. Contrasting resistance and resilience to extreme drought and late spring frost in five major European tree species. Global Change Biology, 2019, 25 (11), pp.3781-3792. 10.1111/gcb.14803 . hal-02523161

\section{HAL Id: hal-02523161 https: / hal.inrae.fr/hal-02523161}

Submitted on 11 May 2020

HAL is a multi-disciplinary open access archive for the deposit and dissemination of scientific research documents, whether they are published or not. The documents may come from teaching and research institutions in France or abroad, or from public or private research centers.
L'archive ouverte pluridisciplinaire HAL, est destinée au dépôt et à la diffusion de documents scientifiques de niveau recherche, publiés ou non, émanant des établissements d'enseignement et de recherche français ou étrangers, des laboratoires publics ou privés. 
DR. YANN VITASSE (Orcid ID : 0000-0002-7454-505X)

DR. MAXIME CAILLERET (Orcid ID : 0000-0001-6561-1943)

DR. PATRICK FONTI (Orcid ID : 0000-0002-7070-3292)

Article type : Primary Research Articles

Contrasting resistance and resilience to extreme drought and late spring frost in five major

European tree species

Running head: Forest resilience to extreme climatic events

Yann Vitasse $^{\mathrm{a}, \mathrm{b}}$, Alessandra Bottero ${ }^{\mathrm{a}, \mathrm{b}}$, Maxime Cailleret ${ }^{\mathrm{a}, \mathrm{b}, \mathrm{c}}$, Christof Bigler ${ }^{\mathrm{b}, \mathrm{d}}$, Patrick Fonti $^{\mathrm{a}, \mathrm{b}}$, Arthur Gessler ${ }^{\mathrm{a}, \mathrm{b}, \mathrm{e}}$, Mathieu Lévesque ${ }^{\mathrm{b}, \mathrm{d}}$, Brigitte Rohner ${ }^{\mathrm{a}, \mathrm{b}}$, Pascale Weber $^{\mathrm{a}}$, Andreas Rigling $^{\mathrm{a}, \mathrm{b}, \mathrm{e}}$, Thomas Wohlgemuth ${ }^{\mathrm{a}, \mathrm{b}}$

${ }^{\mathrm{a}}$ WSL Swiss Federal Institute for Forest, Snow and Landscape Research, Birmensdorf,

Switzerland

${ }^{\mathrm{b}}$ SwissForestLab, Birmensdorf, Switzerland

${ }^{\text {c} U M R ~ R E C O V E R, ~ A i x ~ M a r s e i l l e ~ U n i v, ~ I R S T E A, ~ A i x-e n-P r o v e n c e, ~ F r a n c e ~}$

${ }^{\mathrm{d}}$ Forest Ecology, Department of Environmental Systems Science, ETH Zurich, Zurich, Switzerland

${ }^{\mathrm{e}}$ Institute of Terrestrial Ecology, ETH Zürich, Zürich, Switzerland

\section{Corresponding author: Yann Vitasse}

phone: $+41-32-739-2073$

Email: yann.vitasse@wsl.ch

This article has been accepted for publication and undergone full peer review but has not been through the copyediting, typesetting, pagination and proofreading process, which may lead to differences between this version and the Version of Record. Please cite this article as doi: $10.1111 / \mathrm{gcb} .14803$

This article is protected by copyright. All rights reserved. 
Keywords: climate warming, climatic water balance, dendrochronology, extreme climatic events, frost risk, growing degree days, tree phenology, tree-ring width.

\begin{abstract}
Extreme climate events (ECEs) such as severe droughts, heat waves and late spring frosts are rare but exert a paramount role in shaping tree species distributions. The frequency of such ECEs is expected to increase with climate warming, threatening the sustainability of temperate forests. Here, we analyzed 2844 tree-ring width series of five dominant European tree species from 104 Swiss sites ranging from 400 to $2200 \mathrm{~m}$ a.s.l. for the period 1930-2016. We found that (i) the broadleaved oak and beech are sensitive to late frosts that strongly reduce current year growth; however, tree growth is highly resilient and fully recovers within two years; (ii) radial growth of the conifers larch and spruce is strongly and enduringly reduced by spring droughts - these species are the least resistant and resilient to droughts; (iii) oak, silver fir, and to a lower extent beech, show higher resistance and resilience to spring droughts and seem therefore better adapted to the future climate. Our results allow a robust comparison of the tree growth responses to drought and spring frost across large climatic gradients and provide striking evidence that the growth of some of the most abundant and economically important European tree species will be increasingly limited by climate warming. These results could serve for supporting species selection to maintain the sustainability of forest ecosystem services under the expected increase in ECEs.
\end{abstract}

This article is protected by copyright. All rights reserved. 


\section{INTRODUCTION}

Extreme climate events (ECEs) such as severe droughts, heat waves, and their combination, called 'hot droughts' (Allen et al., 2015), or late spring frosts are rare per definition but may largely impact forest ecosystems. They have been identified worldwide as major environmental factors acting directly or indirectly on growth, mortality and regeneration of a wide array of tree species (Breshears et al., 2005, Hufkens et al., 2012, Allen et al., 2015), ultimately driving their spatial distribution (Smith, 2011). This is especially true for lowelevation temperate forests whose functions and dynamics are largely shaped by extreme droughts (Pederson et al., 2014). For instance, the European spring/summer hot drought in 2003 has caused abrupt and severe decreases in tree productivity and health in western and central Europe, and transiently turned forests into carbon sources (Ciais et al., 2005). In addition, temperate tree species are highly sensitive to late spring frosts during bud break and leaf emergence (Vitra et al., 2017, Bigler \& Bugmann, 2018), and the tree's leaf-out timing in relation to spring frosts may be a key driver of their upper elevational distribution (Körner et al., 2016). Even though trees have evolved to leaf-out at the time when the statistical recurrence of frost is almost nil (Lenz et al., 2016), damaging spring frosts can still occur, in particular when an unusual long warm period in early spring induces premature vegetation development ('false spring', Chamberlain et al., 2019), as it occurred over broad areas in western and central Europe in 2017 (Vitasse \& Rebetez, 2018) or in the eastern part of the USA in 2007 (Gu et al., 2008, Hufkens et al., 2012).

Extreme droughts are expected to increase in frequency, magnitude and spatial extent (Ballester et al., 2010, Stott, 2016, McDowell et al., 2018). To what extent the frequency of damaging spring frosts may change remains more uncertain and site-specific, because both spring phenology and the last spring frosts are currently advancing (Vitasse et al., 2018a). While temperate trees at lower elevations may further suffer from drought in the future 
decades (Pederson et al., 2014), trees at higher elevations may paradoxically be increasingly exposed to spring frosts (Vitasse et al., 2018a) due to above-average phenological shifts (Vitasse et al., 2018b). Thus, in order to adapt forest management for the provision of toppriority ecosystem services in the near future (Lindner et al., 2010), we urgently need to assess the respective short-and long-term responses of major tree species (i.e., their resilience) to both extreme drought and spring frost, the latter being much less studied.

In such a context, the analysis of tree-ring widths is a useful approach to retrospectively assess the growth resistance, recovery, and resilience to ECEs as it reflects a tree's annual aboveground biomass increment and its capacity to withstand extreme drought and spring frost events (Lloret et al., 2011). Here, the term resilience refers to the concept of 'engineering resilience'(Holling, 1996) as the ability of an organism/ecosystem to return to pre-disturbance conditions, distinguishing two components: the resistance (capacity to withstand the disturbance) and the recovery (recovery relative to the response induced by the disturbance episode) (Ingrisch \& Bahn, 2018). These two metrics can be used as early warning signals of an impending critical transition (Dakos et al., 2015). For instance, a decrease in the ability of a tree to recover after a severe drought may be indicative of declining growth and vigor and thus a higher mortality risk (Rogers et al., 2018).

The interannual variability of tree-ring width is among other factors directly and indirectly regulated by climatic conditions via the limitation of the internal carbon sink (the cambial activity) or carbon source (assimilation via photosynthesis or remobilization and availability of the carbohydrates from storage) (Körner, 2015). For instance, spring frosts can heavily damage the new leaves, resulting in a dramatic decrease of the photosynthetic activity especially for deciduous species, typically followed by a significant decline of reserves and allocation to radial growth (Augspurger, 2011). Similarly, during an exceptionally long and/or extremely severe dry period in the growing season, trees may be (i) forced to close 
their stomata to save water, which may simultaneously induce carbon depletion, or (ii) subjected to hydraulic constraints inducing xylem cavitation (McDowell et al., 2008, Choat et al., 2012). As a consequence, drought can terminate the xylogenesis prematurely (Fernándezde-Uña et al., 2017) and can also affect radial growth in subsequent years (Anderegg et al., 2015). However, depending on intensity and exact timing of the ECE, impacts on tree growth might be very different and species-dependent (D'Orangeville et al., 2018). Severe droughts in spring and/or early summer are expected to have the strongest impact on the current year's growth and tree functioning as they occur at early-season peaks in radial growth, when soil water and nutrient availability are normally available in excess and do not limit growth (D'Orangeville et al., 2018).

Tree rings provide a precious archive documenting the direct and lagged effects of both droughts and damaging spring frosts that have occurred during the tree life. As they can be measured on numerous individuals, species, and sites at reasonable cost, they allow to retrospectively analyze the variation in resilience to ECEs among tree species with different life history and physiology, related e.g. to leaf and cambial phenology, stomatal response to drought or hydraulic safety margin. Although some studies have highlighted the differences in drought responses between angiosperms and gymnosperms (Anderegg et al., 2015, Gazol et al., 2018), we still lack of multi-species analyses along broad environmental gradients for extreme drought (but see Gazol et al., 2017) and especially for late spring frost events. In addition, we still need to detect species-specific tipping points of drought or frost intensity beyond which tree-growth clearly decreases.

Here, we evaluated the potential of major European tree species to tolerate severe spring drought and late spring frost by gathering a large dataset of tree-ring width measurements encompassing a total of 2844 trees (represented by one core each) from five different species and 104 different sites across various climatic conditions in Switzerland, from warm and dry 
lowlands to cool and wet subalpine regions. Specifically, we aimed at (i) quantifying the respective impacts of extreme spring frosts and droughts on the resistance, recovery and resilience of radial growth of three major conifer species and two common broadleaved species, and (ii), determining and comparing the tipping points of water deficit and frost risk beyond which radial growth abruptly declines among the five study species.

\section{MATERIALS AND METHODS}

Study species and tree-ring series

Five of the most economically important European tree species were considered in this study, including three coniferous species (silver fir, Abies alba Mill.; Norway spruce, Picea abies (L.) Karst; and European larch, Larix decidua Mill.), and two broadleaved species (European beech, Fagus sylvatica L.; and deciduous oaks, Quercus spp. including pedunculate oak, Quercus robur L. and sessile oak Quercus petraea (Matt.) Liebl., while it cannot be ruled out that downy oak, Quercus pubescens Willd., was present in individual sites). Note that treering data of sessile and pedunculate oak were pooled in our analysis as often done in dendroecological studies because of the difficulty to differentiate the two species in terms of wood anatomy and because of the high proportion of natural hybrids between the two species (Lepais \& Gerber, 2011). For clarity's sake the species are hereafter referred to as fir, spruce, larch, beech and oak.

We gathered existing tree-ring width measurements of these five species from Switzerland that include the period 1930-2011. As data sources, we included numerous datasets published in ISI indexed journals, from the "grey" literature, or made available from the International Tree-Ring Data Bank ITRDB (see details in Table S1). A quality control of each dataset was conducted to test whether each core had been correctly crossdated using the software COFECHA (Holmes, 1983). Cores that were not correctly crossdated or that 
presented strong statistical anomalies in their correlations with the other individuals within the same stand were removed from subsequent analyses. Trees with less than 60 tree rings were discarded because they were difficult to check for the quality of the crossdating, which also allowed to avoid including too young individuals that may respond differently than mature trees to well-known ECEs such as the drought of 1976. The total number of trees discarded for such reasons was, however, very limited (1.8\% of the total sample size). We considered tree populations which are represented by a minimum of five trees per species and site (details about the number of populations and trees per species are provided in Table S2). A total of 2844 cores (one core per tree) have been analyzed from 104 different forest stands in Switzerland spanning an elevational range from 420 to $2200 \mathrm{~m}$ a.s.l. (Figure 1a \& Table S2). The elevational range of the study sites strongly varies depending on species, being the highest for larch and spruce $(>1500 \mathrm{~m})$, the lowest for oak $(<600 \mathrm{~m})$ and intermediate for fir and beech ( 900 m) (Table S2). Annual mean temperature of the different sites ranges from 1.0 to $11.2^{\circ} \mathrm{C}$ and annual precipitation ranges from 893 to $2492 \mathrm{~mm}$ (averages refer to the period 1981-2010, Figure 1b, Table S1).

\section{Climate data}

Daily minimum and maximum temperature and daily precipitation were derived at $100 \mathrm{~m}$ resolution from 1930 to 2016 by interpolating daily values of MeteoSwiss (the Swiss Federal Office of Meteorology and Climatology) weather stations using the Daymet software of Thornton et al. (1997). Daily minimum and maximum temperature and daily precipitation were then extracted for each of the 104 study sites using their geographic coordinates. Daily mean temperature values were computed by averaging daily minimum and maximum temperature data. 


\section{Identifying potentially damaging spring frost}

Spring frost can be damaging to trees, especially when it occurs during or after leaf

emergence when trees are the most sensitive to freezing temperatures (Vitasse et al., 2014). Thus, spring phenology must be accounted for when looking at potentially damaging frosts over the past. Growing degree days, i.e. daily accumulation of mean temperature above a certain threshold in late winter and spring, is a widely used proxy to predict the time of spring phenology phases for natural and cultivated plant species (e.g. Sacks \& Kucharik, 2011). In Switzerland, degree days accumulated from 1 January to mid-April show high correlation with the Swiss spring index $\left(\mathrm{R}^{2}>0.8\right)$, which represents the onset of vegetation development in spring using $~ 80$ weather stations with sufficiently long data series of phenological observations (Vitasse \& Rebetez, 2018). To identify the years with potentially damaging spring frosts, we therefore used accumulated degree days, as a proxy for plant phenology advancement, calculated for every year and station as the sum of daily mean air temperature above $5{ }^{\circ} \mathrm{C}$ since 1 January to the date of the last frost day $\left[\leq-2^{\circ} \mathrm{C}\right.$ : temperature threshold below which damages can be observed on numerous fruit and forest trees, see Vitasse et al. (2018a)]. The higher the degree days accumulated before the frost event, the higher is the risk for plants to be injured by frost, following the method developed by Vitasse and Rebetez (2018). Although young leaves of temperate trees have been shown to resist temperatures below $-2{ }^{\circ} \mathrm{C}$ in the laboratory (Lenz et al., 2013), radiative cooling during clear and windless nights may lead to temperatures in plant tissues several degrees lower than those measured at $2 \mathrm{~m}$ height under the sheltered conditions of a Stevenson screen (Ducrey, 1998). We therefore assume a threshold of $-2^{\circ} \mathrm{C}$ to be low enough to potentially damage leaves of the study species. Besides, this value or very similar thresholds (e.g. $\left.-2.2^{\circ} \mathrm{C}\right)$ are commonly used in other studies (reviewed in Chamberlain et al., 2019). 


\section{Identifying severe droughts}

The Standardized Precipitation Evapotranspiration Index (SPEI) (Vicente-Serrano et al., 2010) was calculated for each site for the period 1930-2016 after aggregating the daily temperature and the precipitation data per month. SPEI can be aggregated over monthly intervals to measure short- to long-term droughts (Vicente-Serrano et al., 2010). When assessing the impact of drought on growth of temperate trees, a critical point is when the drought occurred within the seasonal cycle of the plant (Anderegg et al., 2013). The timing of drought may indeed explain why some species respond more to one drought event than to another (e.g. early summer vs. late summer growth). For example, severe summer drought might be compensated by wet spring or previous winter conditions (Vitali et al., 2018).

However, spring droughts are probably the most detrimental to growth of temperate trees as they need substantial water to supply emerging and growing leaves (Lévesque et al., 2014, Martin-Benito et al., 2018). After testing different time intervals, we selected the period from March to June for the calculation of the SPEI as (i) it maximizes the Pearson correlation between SPEI and the site- and species-specific chronologies of tree-ring indices across species (Figure S1), (ii) it integrates the period and the pre-period of the beginning of the growing season for trees in this area when typically high production rates of xylem cells are observed (Dietrich et al., 2018), and (iii) the largest fraction of water taken up by trees during the growing season comes from early spring (Brinkmann et al., 2018). However, because SPEI allows to identify dry years for a given site but not to compare the drought intensity among sites since it is a standardized index, we further calculated the climatic water balance of every site between March and June. First, we calculated for every site and month the potential evapotranspiration (ETo) based on monthly mean temperatures and latitude using the Thornthwaite equation (Thornthwaite, 1948) implemented in the R package 'SPEI' (Beguería \& Vicente-Serrano, 2013). Second, we subtracted ETo from monthly precipitation 
values, which provides the climatic water balance of each site at monthly scale. As for the SPEI, we finally aggregated the climatic water balance over the period from March to June.

\section{Data analyses and statistics related to tree-ring series}

For every individual tree and every year we calculated the resistance, recovery and resilience indices based on Lloret et al. (2011), as following:

Resistance $(R t)=\frac{\text { Ring width }}{\text { Ring } \text { width }_{t-2}}$

Recovery $(R c)=\frac{\text { Ring } \text { width }_{t+2}}{\text { Ring } \text { width }_{t}}$

Resilience $(R s)=\frac{\text { Ring } \text { width }_{t+2}}{\text { Ring } \text { width }_{t-2}}$

where Ring width $_{t}$ is the radial width of the annual ring during the corresponding year $t$, Ring width $_{t-2}$ is the average ring width for the 2 years preceding the year $t$ and Ring $_{\text {widt }} h_{t+2}$ is the average ring width for the 2 years following the year $t$. All these indices were calculated at the individual tree level for each year during the period 1930-2011 (and later when available) and then averaged per site and species. We selected two years to ensure that the lag effect of a given extreme climatic event does not overlap with another extreme event (Anderegg et al., 2015), which was the case at least for the two main identified late spring frosts (1957 and 1981, Fig. 2a) and spring droughts (1976 and 2003, Fig. 2b).

To assess the growth-SPEI relationships, we built a mean-value chronology of the tree-ring width indices at every site. Tree-ring width series of each individual tree were detrended with a $50 \%$ frequency-response at a wavelength of $2 / 3$ of each series length (Cook \& Kairiukstis, 1990). Then, the resulting indices were averaged using Tukey's biweight robust mean to get the site chronologies (R package “dplR”) (Bunn, 2008).

This article is protected by copyright. All rights reserved. 


\section{Statistics}

To predict the resistance, recovery and resilience indices in relation to growing degree days reached at the last spring frost and to the water deficit from March to June, we used generalized additive mixed models (GAMMs) using the function "gamm4" in the R package "gamm4". The models included a smoothing spline with 4 degrees of freedom for either growing degree days at the last spring frost or the climatic water deficit, with tree species as a factor modulating the spline and the site as a grouping variable for the random intercept. The fitted GAMMs with the associated means and confidence intervals allowed us to compare the species-specific resistance, recovery and resilience to frost and spring drought for the same magnitude of stress. F values and significance levels of the smooth terms of these models are provided in Table S5.

All data analyses and statistics were performed using RStudio version 0.99.489 (R Core Team, 2015).

\section{RESULTS}

Impact of damaging spring frosts on growth

Across the 104 study sites, the two years 1957 and 1981 were those having, on average, the highest meteorologically defined risk of spring damaging frost during the period 1930-2016 (Figure 2a). A high frost risk was also detected locally in other years such as in 2007 for sites at elevations between 1300 and 1700 m a.s.l. or in 1945, 1953, 1959 and 1974 for lower elevation sites (Figure 2a). On average over the study period, 52 degree days were reached at the time of the last spring frost below $-2^{\circ} \mathrm{C}$ (as a proxy for the risk of frost damage, see methods), while it exceeded 140 degree days in 1957 and 1981 with values beyond 200 degree days in $43 \%$ and $37 \%$ of all sites, respectively, mostly at lower elevations (Figure 2a). These two years were not particularly dry (i.e. slightly negative and positive SPEI values 
across sites in 1957 and 1981, respectively; Figure S2), so that there is no confounding effect with drought.

During these two years radial growth was strongly reduced for the two broadleaved species only, namely beech and oak (Figure 3). Resistance index plotted for all sites and all years in relation to the accumulated degree days reached at the last frost $\leq-2^{\circ} \mathrm{C}$ showed a significant decline beyond 200-220 degree days for beech and oak only, which mainly occurred in 1957 and 1981 at low-elevation sites (Figure 4a \& Figure S3). Beyond this threshold, the resistance index was on average below 0.85 (i.e. $>15 \%$ of growth reduction) for both beech and oak with values lower than 0.73 in 1957 across sites (i.e. >27\% of growth reduction, Fig. S4). Resistance values lower than 0.5 (i.e. more than $50 \%$ of growth reduction) were even found at a few sites (minimum of 0.27 for beech at one site in 1957, Figure S4 \& Figure S5). GAMMs predicted mean resistance values $\leq 0.75$ for both beech and oak beyond 300 degree days at the time of the last frost $<-2^{\circ} \mathrm{C}$ (Figure $4 \mathrm{a}$, \& Figure S3, Table S3).

Both species, however, fully recovered in the two years following these damaging spring frosts, leading to resilience values close to 1 for beech or even slightly higher for oak (Figure 4a, \& Figure S3, Table S3). In contrast, no growth decline was detected in response to these two late spring frost events for the three conifers, including the deciduous species larch (Figure 4a and Fig. S3, Table S3).

\section{Impact of extreme spring droughts and summer temperature on growth}

Our meteorological analysis revealed 1976 and 2003 as the driest springs observed from 1930 to 2016, with negative climatic water balance between March and June found for 58\% (1976) and $70 \%$ (2003) of all the study sites (Figure $2 \mathrm{~b} \&$ Figure S6). Tree-ring width chronologies obtained for each site and species clearly showed that these two driest springs had a significant impact on current year growth for most species, especially at lower elevations (though less pronounced for oak in 2003, Figure 3). All species showed a significant 
reduction in growth resistance when the climatic water balance from March to June was negative (Figure $4 b$ \& Figure S7). However, the magnitude of this growth reduction in response to drought as well as the recovery and resilience within the following two years greatly differed among the species. For a water balance of $-200 \mathrm{~mm}$, predicted values of the resistance index from the GAMMs were lowest for spruce $(0.60 \pm 0.05)$ and larch $(0.65 \pm 0.06)$, intermediate for beech $(0.73 \pm 0.04)$ and highest for fir $(0.81 \pm 0.06)$ and oak $(0.84 \pm 0.04)$ (Fig. 4b \& Table S4).

Remarkably, in spite of a recovery index well above 1, spruce and larch did not reach their pre-drought growth rates two years after extreme droughts (resilience index $<0.87$ ), whereas beech, oak and fir showed resilience values close to 1 (Fig. 4b \& Table S4). Thus, fir and oak were more resistant and resilient than spruce and larch to extreme droughts. Beech presented intermediate values of resistance but a high resilience (Fig. 4b \& Table S4). To test the robustness of this pattern, we additionally assessed pre- and post-periods of 3 and 4 years before and after the drought and found very similar results (Figure S8 and Table S4). More importantly, these results demonstrate that the lag effect of extreme droughts persisted for at least four years for spruce and larch, which contrasted with the growth of oak, beech and fir that fully recovered within 2 years (Figure S8 \& Table S4).

Spruce and larch also showed a strong dependence of tree growth to mean summer temperature in relation to elevation. Below $\sim 1300 \mathrm{~m}$ most populations of these two species exhibited negative relationships between summer temperature and tree-ring indices, while the opposite was found for higher elevations (Figure 5). For beech and oak, both positive and negative relationships were found at lower elevations. Remarkably, a positive or null effect of warmer summer temperature was detected for all populations of fir, irrespective of elevation (Figure 5). 


\section{DISCUSSION}

Extreme drought events are expected to increase in Europe in both magnitude and frequency (Ballester et al., 2010), while the risk of damaging spring frosts on major tree species remains uncertain for the future, but should persist in Europe or even increase in some regions due to earlier spring phenology (Ma et al., 2019). To provide a solid basis for decision-making regarding the future selection of species and provenances matching the changing environment, there is an urgent need to assess their specific responses to both drought and spring frost. Using tree-ring width series from 2'844 trees growing under a wide range of climatic conditions in central Europe, our results reveal strong disparities in the species resilience to both extreme events. An impact of spring frosts on tree growth was only detected for the two broadleaved species (beech and oak) with a magnitude that often exceeded the effects of extreme drought events. Nevertheless, both species quickly recovered after such damaging frosts. More importantly, our analysis allows comparing the resilience of the focal species to extreme droughts of similar magnitude. While oak, fir, and to a lower extent beech could moderately cope with severe droughts, spruce and larch poorly resisted and recovered after such events.

\section{Damaging spring frosts}

Damaging spring frosts are assumed to cause growth reduction due to the shortening of the growing season and the cost of additional carbon resources to produce new leaves (Augspurger, 2009). Our study highlights the lower resistance of angiosperms to late frosts compared to gymnosperms (including deciduous species such as larch). This result could be due to differences in their coupling between leaf and wood phenology, in intra-annual nonstructural carbohydrates (NSC) dynamics, or in their different GDD requirement. More particularly, (i) evergreen gymnosperms carry multiple needle generations and older needles 
are generally more resistant to frost than new needles in spring (but see Bachofen et al., 2016 for pines), and can therefore compensate for photosynthesis when the new needles are damaged (except for the deciduous larch); (ii) beech is characterized by stronger dependence of radial growth to leaf photosynthesis rather than to stored stem NSC, showing low growth rates until leaves are fully developed (Michelot et al., 2012). However, a strong contribution of stored carbon to early wood growth has been postulated for beech in other studies (Helle \& Schleser, 2004, Skomarkova et al., 2006). In contrast to evergreen coniferous species, which mainly use NSC from old needles to produce the new flush, deciduous trees rely on stem and branch NSC for leaf development (Egger et al., 1996), and thus a preferred allocation of carbon from these storage pools for leaf repair or to a second leaf flush might strongly compete with radial stem growth. (iii) Finally, the two studied conifer species are known to have quite an early (larch) and late (spruce) budbreak (Bigler \& Bugmann, 2018). Larch could therefore be more exposed to spring frosts but has a higher freezing resistance (LT50 of $\sim-7^{\circ} \mathrm{C}$, Taschler \& Neuner, 2004, Bigler \& Bugmann, 2018) whereas spruce may largely avoid late spring frosts as it requires higher GDD to develop new needles (Vitasse et al., 2018a). Our method that uses the accumulation of degree days from mid winter to the last potentially damaging frost as a proxy for the frost risk, proved to be reliable as it shows an abrupt decline of radial growth when this accumulation exceeds $\sim 200$ degree days for both angiosperm species. This threshold seems sufficient to trigger leaf-out of many European broadleaved species (Fu et al., 2015, Vitasse et al., 2018a), although short photoperiod in early spring may prevent too precocious leaf-out for some species such as beech (Fu et al., 2019). Furthermore, our results identified 1957 and 1981 as the two years with the highest meteorologically defined risk of spring damaging frost during the study period across all sites, which is consistent with the damage reported in orchards in the Swiss weather archive from MeteoSwiss (annual reports available at 
https://www.meteoswiss.admin.ch/home/climate.html). Interestingly, our results show no carry over effect of the impact of damaging frost for the two broadleaved species on radial growth of the two next years, as also found recently for beech in Germany after local spring frosts (Príncipe et al., 2017). This is likely because trees are able to produce a new cohort of leaves during the same growing season, allowing to refill carbon reserve later in autumn (Zohner et al., 2019). However, a secondary bud flush later in the same growing season may cause a depletion of plant carbon reserves at a time when water and nutrient availability is generally lower, which may weaken tree defenses against diseases and insect pests (McDowell et al., 2011), an aspect that has remained largely unconsidered so far.

\section{Extreme spring droughts}

Our results suggest that spruce, larch and to a lower extent beech exhibit rather low resistance and resilience to extreme spring droughts whereas oak and fir are more tolerant. Although the link between radial growth and tree vitality is not straightforward, severe droughts can induce negative plant water potentials that inhibit cell division and expansion resulting in cessation of xylogenesis and longer periods of stomatal closure (Ryan, 2011). Severe droughts can further lead to hydraulic failure caused by xylem embolism if the tension in the xylem water becomes too high (Choat et al., 2012) and the loss of hydraulic conductivity vs. the ability to regain functional xylem might affect species-specific recovery (Yin \& Bauerle, 2017). NSC storage has been shown to be maintained under lower carbon availability at the expense of biomass accumulation in various tree species (Weber et al., 2019) thus offering an explanation for reduced radial growth. Moreover, both hydraulic and carbon constraints (Herms \& Mattson, 1992, McDowell et al., 2011) can lead to general metabolic limitations as indicated by impaired carbon transport from sources to sinks (Ruehr et al., 2009) or reduced allocation to defense compounds (McDowell et al., 2008) and the consequences thereof 
might strongly determine the recovery trajectories. Our findings are in agreement with recent dendroecological studies showing a higher vulnerability of spruce and larch to drought than fir (van der Maaten-Theunissen et al., 2012, Lévesque et al., 2013, Vitali et al., 2017), which is also in line with studies showing a high sensitivity of spruce to elevated VPD (Sanginés de Cárcer et al., 2018) and the inability of its root system to access deep water layers during summer drought (Brinkmann et al., 2019). Our study also confirms that sessile and pedunculate oaks are able to cope with severe hot drought, as previously suggested in a study focusing on its water status and photosynthesis during the extremely hot drought in 2003 (Leuzinger et al., 2005).

\section{European tree species under global warming}

Our results demonstrate contrasting resistance and resilience of major European tree species to ECEs with spruce and larch exhibiting the highest vulnerability to severe droughts. Thus, if the frequency of ECEs increases, competition among tree species may change, resulting in structural and functional changes within forest ecosystems (McDowell et al., 2018). Besides, our results underline that spruce and larch are not only constrained by severe spring droughts but also by warmer summer temperatures resulting in a strong dependency of tree growth to mean summer temperature in relation to elevation. Over the past decades, warmer summers enhanced the radial growth of these two species above $\sim 1300 \mathrm{~m}$ but reduced it below this elevation. In contrast, we found that warmer summers had neutral to beneficial effects on the radial growth of silver fir, even at low elevation sites. In addition, fir is the only species for which the SPEI calculated over the summer months was on average across sites negatively correlated with tree-ring width chronologies indicating increased growth under drier conditions (Figure S1). This surprising result may be related to its deep-rooting system, which allows to profit from high temperatures often associated with drier conditions in 
summer without substantial water limitation, and to its early growth in spring (Vitasse et al., 2019). Our study area, however, is situated in the core of the species distribution and different results might be expected at warmer and drier sites. For example, silver fir has been reported to decline at the southern margin of its distribution in the Spanish Pyrenees, likely as a consequence of the cumulative effect of very dry years that have followed the exceptionally warm and dry summer of 2003 (Linares \& Camarero, 2012, Gazol et al., 2015).

Although the time window from March to June was best correlated with the tree-ring index (Fig. S1) and encompasses the beginning of tree radial growth, species may have different periods of drought sensitivity. For instance, in some regions radial growth of silver fir has been shown to be sensitive to previous summer-autumn conditions and radial growth of beech to previous summer conditions (Pasho et al., 2012, Vicente-Serrano et al., 2014). Our results are still relevant to show how extreme spring droughts affect radial growth of different species but do not account for previous winter or summer conditions. Biotic factors that were not considered in this study, such as the occurrence of mast years and insect outbreaks, may also strongly affect radial growth and their frequency could also change under future warmer climate. For example, recent studies highlighted a strong radial growth reduction during and after mast years for beech (Hacket-Pain et al., 2018) or during and after larch budmoth outbreak for larch (Peters et al., 2017). Although we cannot rule out the influence of mast years in our study, the influence of larch budmoth outbreak should not affect our result concerning the impact of spring droughts for this species as critical climatic water balance was found only at low-elevation sites where the larch budmoth is absent.

Because global warming is increasing the frequency and magnitude of drought events and advancing spring phenology, the probability that a damaging frost would occur in the same year as an extreme drought is likely to increase in the next decades. Besides, the resilience to ECEs may quickly decline if their frequency reaches a critical level. Hence, more 
investigations are necessary to assess the cumulative and cascading long-term effects of damaging frost and spring/summer drought on tree vigor if they occur within the same year or in consecutive years as they may deplete tree carbon reserves and promote favorable conditions for pests and pathogens.

\section{CONCLUSIONS}

Our results allow for a robust comparison of the vulnerability of major European tree species to spring frosts and droughts. While the two broadleaved species, oak and beech, are less resistant to late spring frosts than coniferous species, they are still highly resilient to frost. However, as for the other species, they show lower resilience to extreme drought, likely because drought affects the hydraulic integrity of the xylem while late spring frost affects mainly leaves. Among conifers, larch and spruce showed the strongest growth reduction in response to severe droughts while fir and oak showed higher resistance and resilience to such events. Providing that the frequency of damaging frost does not increase, deciduous oak species and fir seem better adapted to the projected warmer and drier climate conditions in lowlands of central Europe and should therefore be promoted on suitable sites to ensure healthy forests providing multiple ecosystem services.

\section{ACKNOWLEDGMENTS}

This study has been funded by the SwissForestLab. We are grateful to Dirk Schmatz for providing the gridded DAYMET data. We thank Magdalena Nötzli for her assistance in the data quality check. Y.V, C.B., M.C., A.B., P.F. and T.W. designed the research. Y.V. analyzed the data and wrote the paper with substantial inputs from all co-authors. M.L., B.R. and P.W. provided parts of the tree-ring data. We are grateful to Marco Vanoni and all data contributors for providing tree-ring datasets and also would like to acknowledge the 
international tree-ring data base. We are grateful to Christian Rellstab, Christoph Sperisen, Heike Lischke, Peter Waldner and Roman Zweifel for their seminal contributions for the project. We thank the two anonymous reviewers for their helpful comments on the manuscript.

\section{Figure Captions}

Fig. 1. Location and climatic characteristics of the study sites. (a) Location of the 104 study sites in Switzerland; (b) Mean annual precipitation and temperature of the study sites. Note that the symbols used for the different species differ in size only for a better visualization.

Fig. 2. Identification of the most damaging spring frost and extreme drought years. (a) Degree days reached at the last spring frost $\leq-2{ }^{\circ} \mathrm{C}$ for all 104 sites. Following the method developed in Vitasse and Rebetez (2018), the higher the growing degree days accumulated before the frost event, the higher is the risk for plants to be injured by frost. Across all sites 1957 and 1981 were on average the two most severe springs in terms of frost risk during the period 1930-2016 and are represented with vertical violet dashed lines. The damaging spring frost events of 1957 and 1981 occurred on May 8, and on April 19, respectively. (b) Climatic water balance (precipitation - potential evapotranspiration) from March to June in all 104 sites. Across all sites 1976 and 2003 were on average the two driest springs during the period 1930-2016 and are represented with vertical red dashed lines. In both panels, the orange line represents the average across all sites.

Fig. 3. Tree-ring width chronology of each study population. Chronologies per site were obtained using spline models to detrend each individual tree-ring series. Red dashed lines correspond to the drought years 1976 and 2003, whereas the violet dashed lines correspond to 
the spring frosts 1957 and 1981. Orange lines represent the species-specific averages across all sites.

Fig. 4. Prediction and $95 \%$ confidence intervals of the GAMM models for the resistance (top panels), recovery (middle panels) and resilience indices (bottom panels) considering all years depending on (a) degree days accumulated before the last frost event $\leq-2^{\circ} \mathrm{C}$ as a proxy for the risk of frost and (b) water balance from March to June. The resistance, recovery and resilience indices were calculated using a pre- and post-period of two years (see methods).

Fig. 5. Slopes of the linear regressions between summer air temperature (May-August, 19302016) and tree-ring width chronology for each site in relation to elevation. Black dots correspond to significant slopes at $\mathrm{P}<0.05$. Significant linear regression lines $(\mathrm{P}<0.05)$ are represented in red.

This article is protected by copyright. All rights reserved. 
Figures

Figure 1

(a)

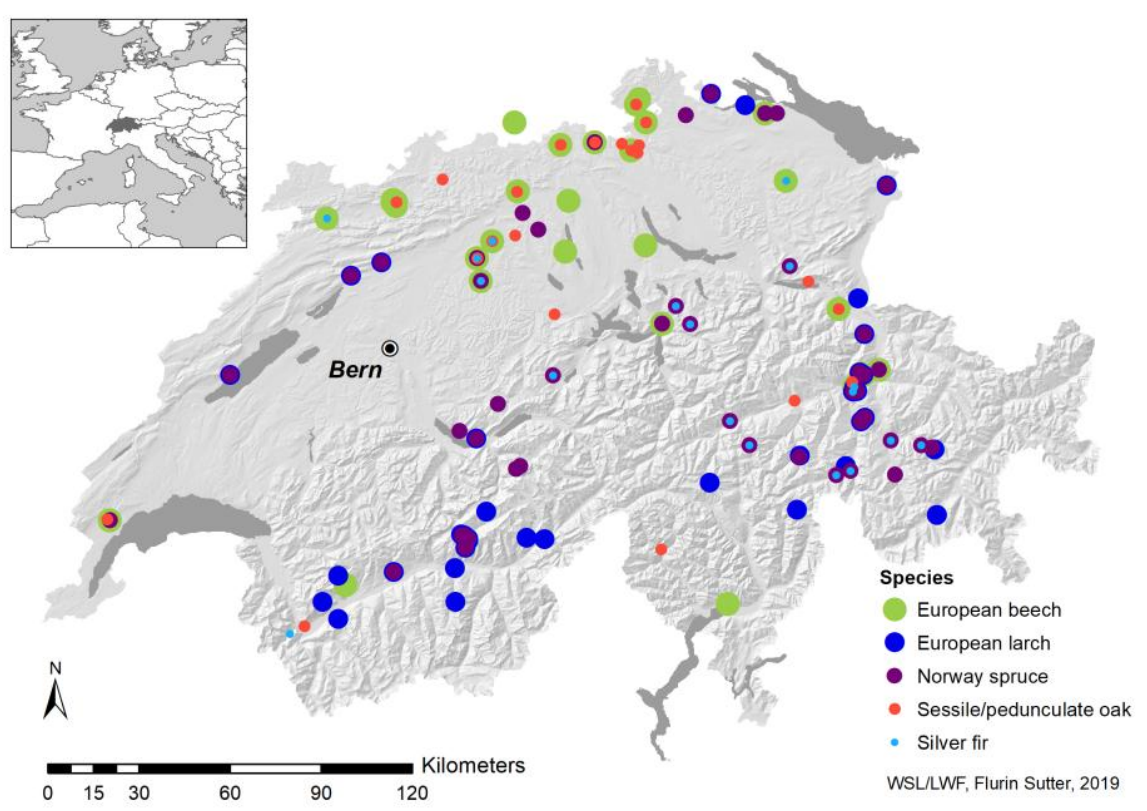

(b)

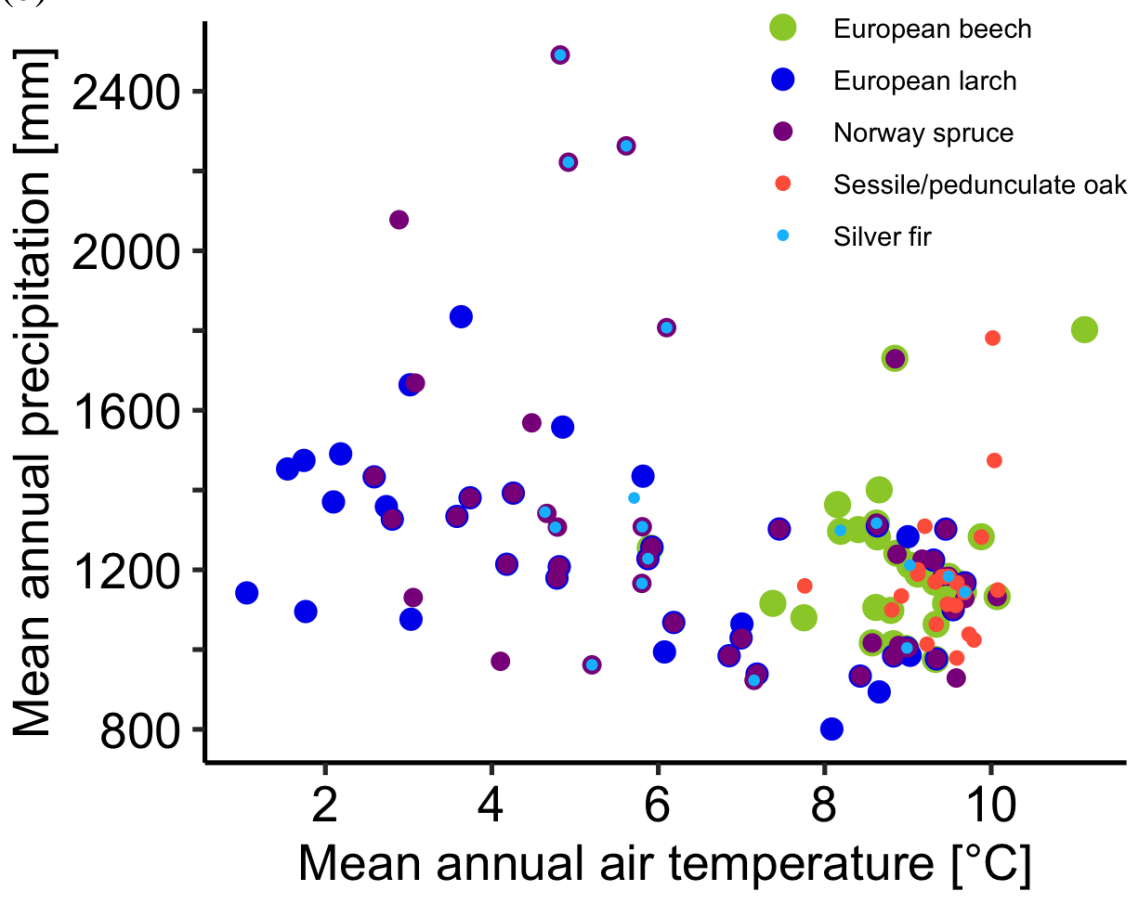

This article is protected by copyright. All rights reserved. 
Figure 2

(a)

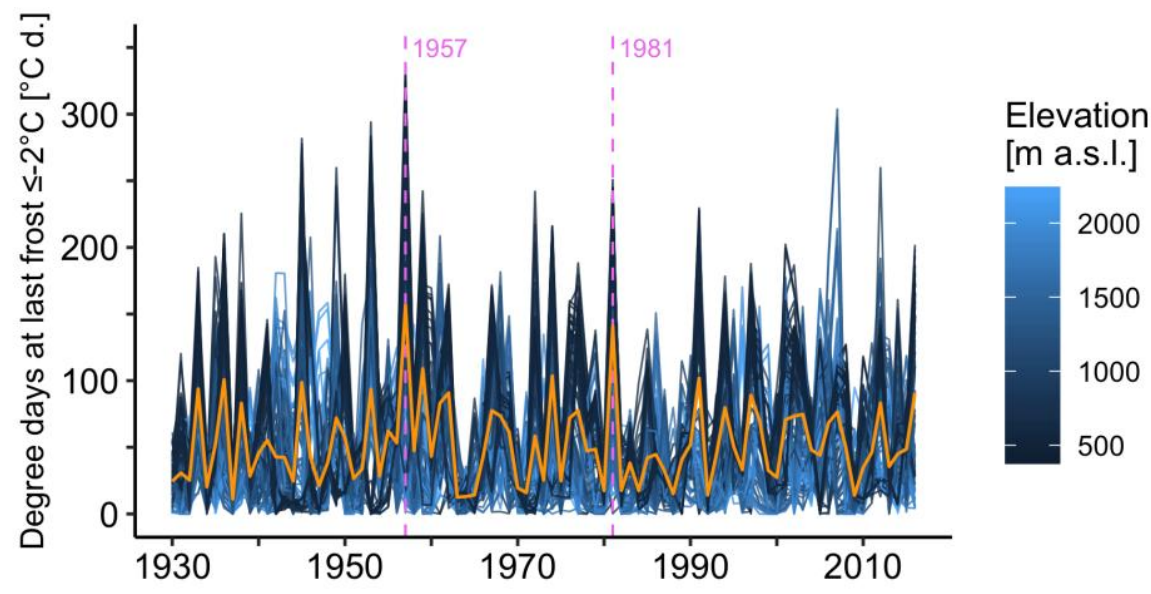

(b)

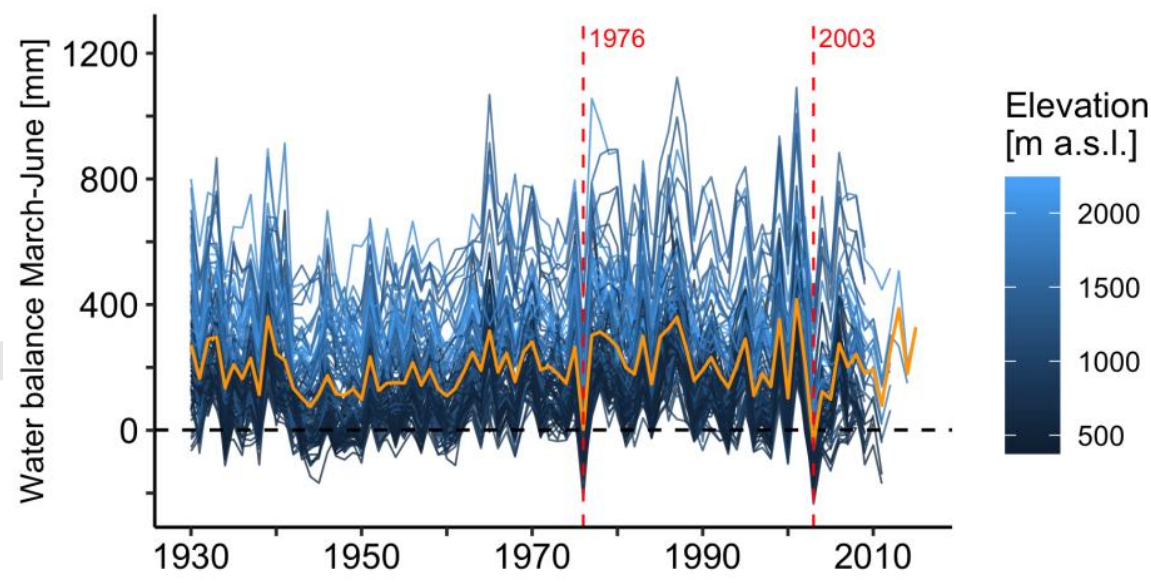

This article is protected by copyright. All rights reserved. 
Figure 3
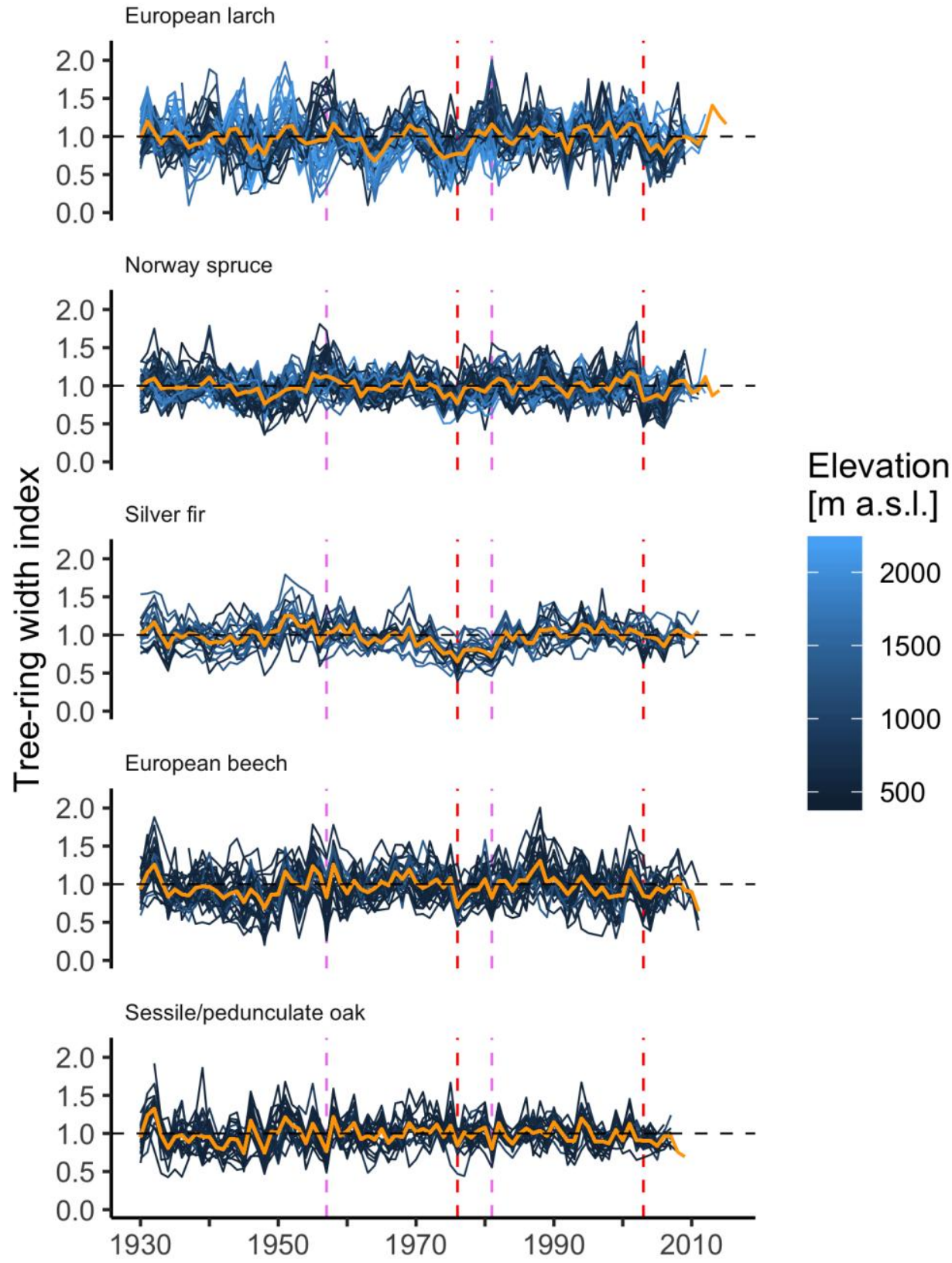

This article is protected by copyright. All rights reserved. 
Figure 4

(a)
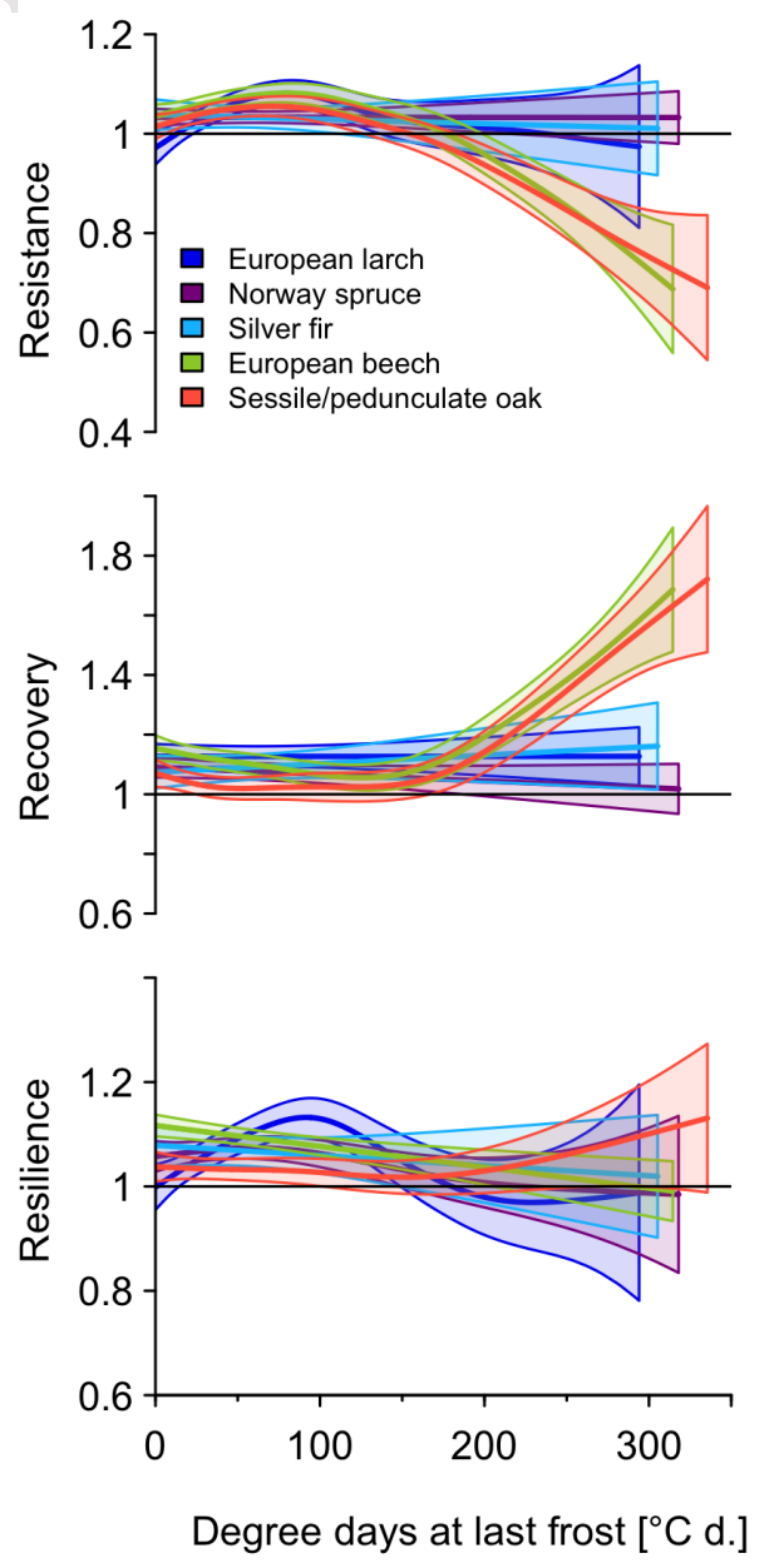

(b)
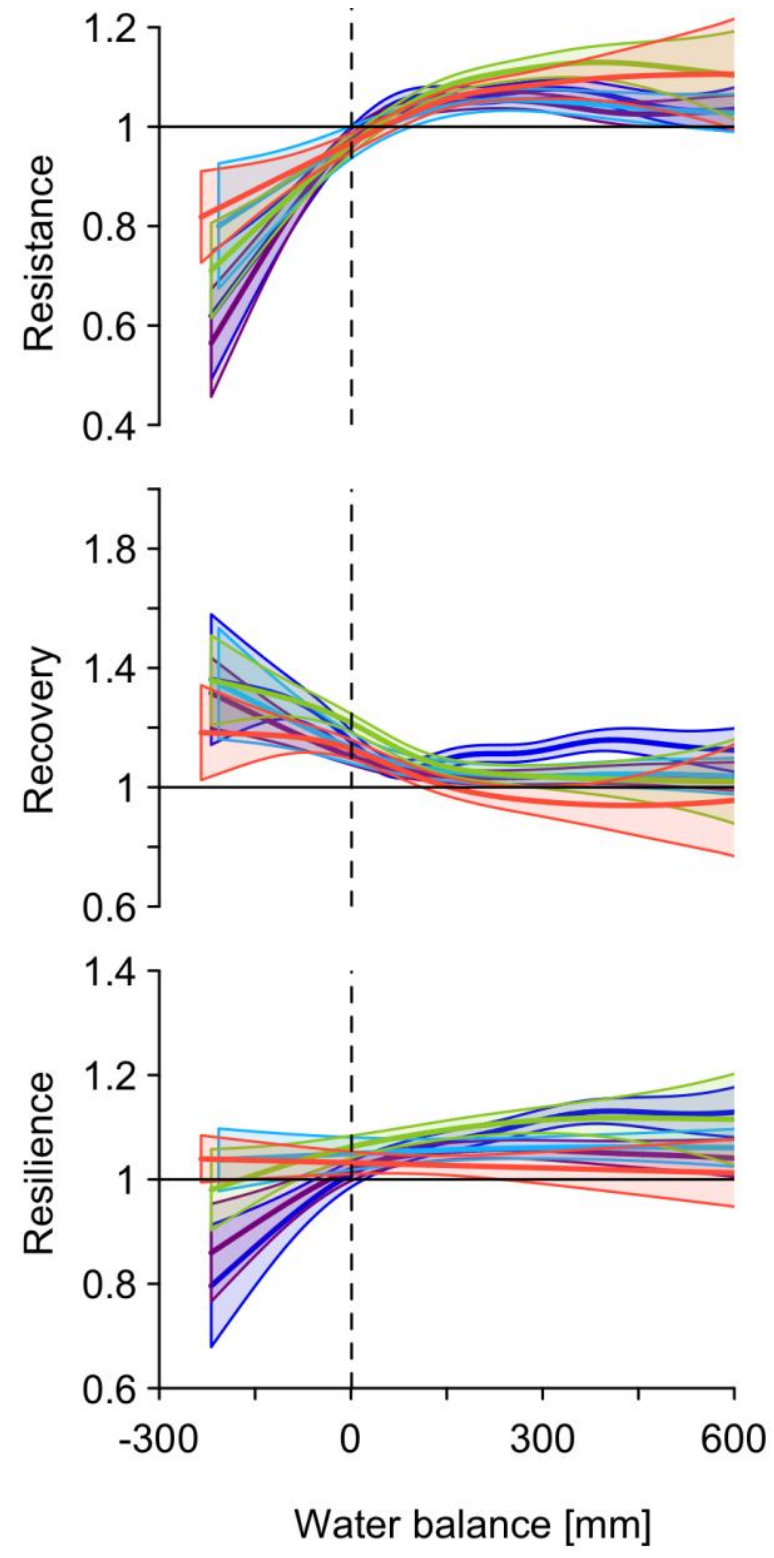

This article is protected by copyright. All rights reserved. 
Figure 5

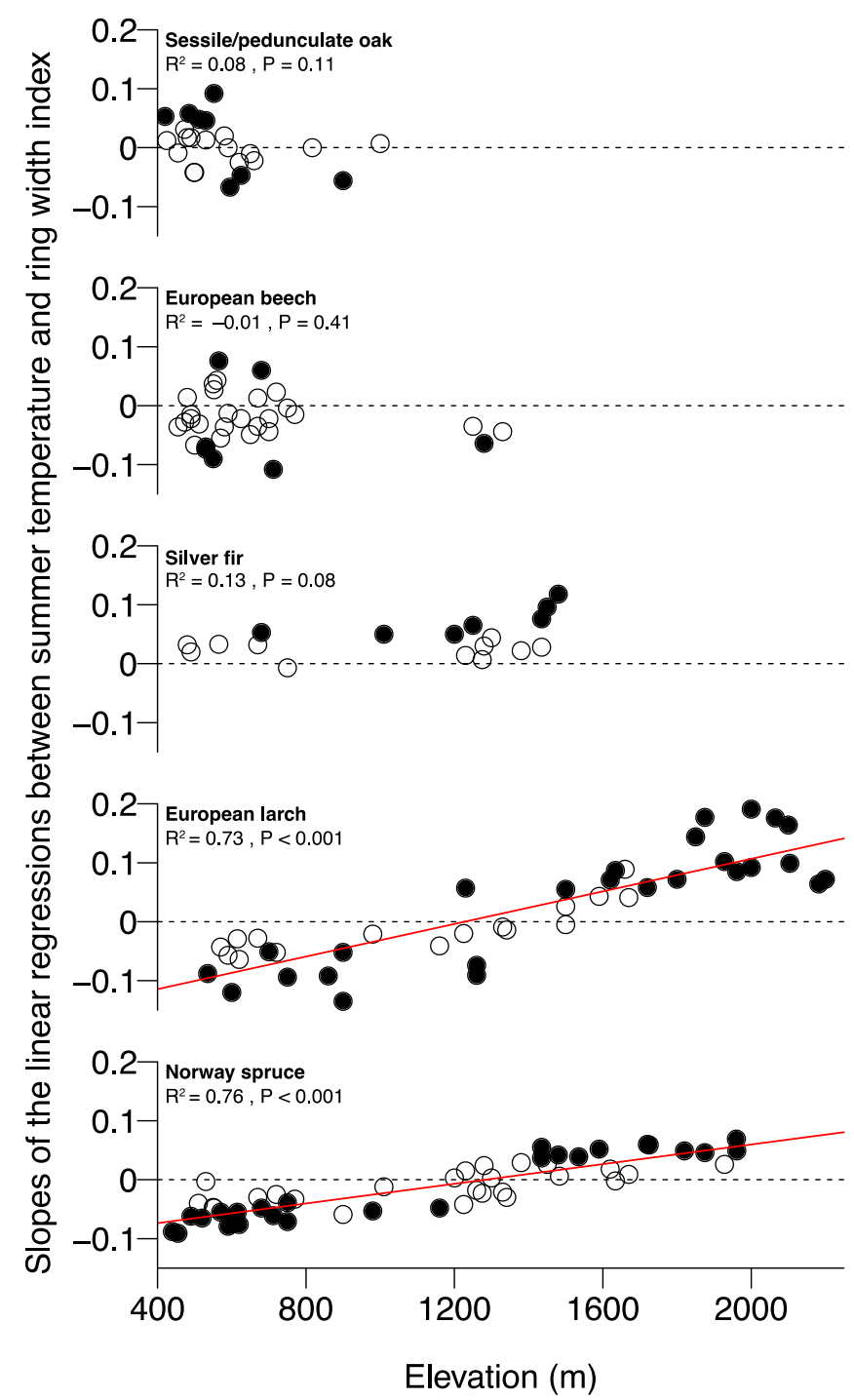

This article is protected by copyright. All rights reserved. 


\section{REFERENCES}

Allen CD, Breshears DD, McDowell NG (2015) On underestimation of global vulnerability to tree mortality and forest die-off from hotter drought in the Anthropocene. Ecosphere, 6, 1-55.

Anderegg LD, Anderegg WR, Berry JA (2013) Not all droughts are created equal: translating meteorological drought into woody plant mortality. Tree Physiology, 33.

Anderegg WR, Schwalm C, Biondi F et al. (2015) Pervasive drought legacies in forest ecosystems and their implications for carbon cycle models. Science, 349, 528-532.

Augspurger CK (2009) Spring 2007 warmth and frost: phenology, damage and refoliation in a temperate deciduous forest. Functional Ecology, 23, 1031-1039.

Augspurger CK (2011) Frost damage and its cascading negative effects on Aesculus glabra. Plant Ecology, 212, 1193-1203.

Bachofen C, Wohlgemuth T, Ghazoul J, Moser B (2016) Cold temperature extremes during spring do not limit the range shift of Mediterranean pines into regions with intermittent frost. Functional Ecology, 30, 856-865.

Ballester J, Rodó X, Giorgi F (2010) Future changes in Central Europe heat waves expected to mostly follow summer mean warming. Climate Dynamics, 35, 1191-1205.

Beguería S, Vicente-Serrano SM (2013) SPEI: calculation of the standardised precipitationevapotranspiration index. R package version, $\mathbf{1}, 6$.

Bigler C, Bugmann H (2018) Climate-induced shifts in leaf unfolding and frost risk of European trees and shrubs. Scientific Reports, 8, 9865.

Breshears DD, Cobb NS, Rich PM et al. (2005) Regional vegetation die-off in response to global-change-type drought. Proceedings of the National Academy of Sciences of the United States of America, 102, 15144-15148.

Brinkmann N, Eugster W, Buchmann N, Kahmen A (2019) Species-specific differences in water uptake depth of mature temperate trees vary with water availability in the soil. Plant Biology, 21, 71-81.

Brinkmann N, Seeger S, Weiler M, Buchmann N, Eugster W, Kahmen A (2018) Employing stable isotopes to determine the residence times of soil water and the temporal origin of water taken up by Fagus sylvatica and Picea abies in a temperate forest. New Phytologist, 219, 1300-1313.

Bunn AG (2008) A dendrochronology program library in R (dplR). Dendrochronologia, 26, 115-124.

Chamberlain CJ, Cook BI, Garcia de Cortazar-Atauri I, Wolkovich EM (2019) Rethinking false spring risk. Global Change Biology, 25, 2209-2220.

Choat B, Jansen S, Brodribb TJ et al. (2012) Global convergence in the vulnerability of forests to drought. Nature, 491, 752.

Ciais P, Reichstein M, Viovy N et al. (2005) Europe-wide reduction in primary productivity caused by the heat and drought in 2003. Nature (London), 437, 529-533.

Cook ER, Kairiukstis LA (1990) Methods of dendrochronology: applications in the environmental sciences, , Dordrecht, Boston, London,, Kluwer Academic Publishers.

D'Orangeville L, Maxwell J, Kneeshaw D et al. (2018) Drought timing and local climate determine the sensitivity of eastern temperate forests to drought. Global Change Biology, 24, 2339-2351.

Dakos V, Carpenter SR, van Nes EH, Scheffer M (2015) Resilience indicators: prospects and limitations for early warnings of regime shifts. Philosophical Transactions of the Royal Society B: Biological Sciences, 370, 20130263.

Dietrich L, Zweifel R, Kahmen A (2018) Daily stem diameter variations can predict the canopy water status of mature temperate trees. Tree Physiology, 38, 941-952.

This article is protected by copyright. All rights reserved. 
Ducrey M (1998) Aspects écophysiologiques de la réponse et de l'adaptation des sapins méditerranéens aux extrêmes climatiques: gelées printanières et sécheresse estivale.

Egger B, Einig W, Sclereth A, Wallenda T, Magel E, Loewe A, Hampp R (1996) Carbohydrate metabolism in one-and two-year-old spruce needles, and stem carbohydrates from three months before until three months after bud break. Physiologia Plantarum, 96, 91-100.

Fernández-de-Uña L, Rossi S, Aranda I, Fonti P, González-González BD, Cañellas I, GeaIzquierdo G (2017) Xylem and leaf functional adjustments to drought in Pinus sylvestris and Quercus pyrenaica at their elevational boundary. Frontiers in Plant Science, 8, 1200.

$\mathrm{Fu}$ YH, Piao S, Vitasse Y et al. (2015) Increased heat requirement for leaf flushing in temperate woody species over 1980-2012: effects of chilling, precipitation and insolation. Global Change Biology, 21, 2687-2697.

Fu YH, Piao S, Zhou X, Geng X, Hao F, Vitasse Y, Janssens IA (2019) Short photoperiod reduces the temperature sensitivity of leaf-out in saplings of Fagus sylvatica but not in Horse chestnut. Global Change Biology, 25, 1696-1703.

Gazol A, Camarero J, Anderegg W, Vicente-Serrano S (2017) Impacts of droughts on the growth resilience of Northern Hemisphere forests. Global Ecology and Biogeography, 26, 166-176.

Gazol A, Camarero JJ, Gutiérrez E et al. (2015) Distinct effects of climate warming on populations of silver fir (Abies alba) across Europe. Journal of Biogeography, 42, 1150-1162.

Gazol A, Camarero JJ, Vicente-Serrano SM et al. (2018) Forest resilience to drought varies across biomes. Global Change Biology, 24, 2143-2158.

Gu L, Hanson PJ, Mac Post W et al. (2008) The 2007 eastern US spring freezes: Increased cold damage in a warming world? Bioscience, 58, 253-262.

Hacket-Pain AJ, Ascoli D, Vacchiano G et al. (2018) Climatically controlled reproduction drives interannual growth variability in a temperate tree species. Ecology Letters, 21, $1833-1844$.

Helle G, Schleser GH (2004) Beyond CO2-fixation by Rubisco - an interpretation of $13 \mathrm{C} / 12 \mathrm{C}$ variations in tree rings from novel intra-seasonal studies on broad-leaf trees. Plant, Cell \& Environment, 27, 367-380.

Herms DA, Mattson WJ (1992) The dilemma of plants: to grow or defend. The quarterly review of biology, 67, 283-335.

Holling CS (1996) Engineering resilience versus ecological resilience. Engineering within ecological constraints, 31, 32 .

Holmes RL (1983) Computer-assisted quality control in tree-ring dating and measurement. Tree-ring bulletin.

Hufkens K, Friedl MA, Keenan TF, Sonnentag O, Bailey A, O'Keefe J, Richardson AD (2012) Ecological impacts of a widespread frost event following early spring leaf-out. Global Change Biology, 18, 2365-2377.

Ingrisch J, Bahn M (2018) Towards a comparable quantification of resilience. Trends in Ecology \& Evolution.

Körner C (2015) Paradigm shift in plant growth control. Current Opinion in Plant Biology, 25, 107-114.

Körner C, Basler D, Hoch G et al. (2016) Where, why and how? Explaining the low temperature range limits of temperate tree species. Journal of Ecology, 104, 10761088.

This article is protected by copyright. All rights reserved. 
Lenz A, Hoch G, Körner C, Vitasse Y (2016) Convergence of leaf-out timing towards minimum risk of freezing damage in temperate trees. Functional Ecology, 30, 14801490.

Lenz A, Hoch G, Vitasse Y, Korner C (2013) European deciduous trees exhibit similar safety margins against damage by spring freeze events along elevational gradients. New Phytologist, 200, 1166-1175.

Lepais O, Gerber S (2011) Reproductive patterns shape introgression dynamics and species succession within the European white oak species complex. Evolution, 65, 156-170.

Leuzinger S, Zotz G, Asshoff R, Körner C (2005) Responses of deciduous forest trees to severe drought in Central Europe. Tree Physiology, 25, 641-650.

Lévesque M, Rigling A, Bugmann H, Weber P, Brang P (2014) Growth response of five cooccurring conifers to drought across a wide climatic gradient in Central Europe. Agricultural and Forest Meteorology, 197, 1-12.

Lévesque M, Saurer M, Siegwolf R, Eilmann B, Brang P, Bugmann H, Rigling A (2013) Drought response of five conifer species under contrasting water availability suggests high vulnerability of Norway spruce and European larch. Global Change Biology, 19, 3184-3199.

Linares JC, Camarero JJ (2012) Growth patterns and sensitivity to climate predict silver fir decline in the Spanish Pyrenees. European Journal of Forest Research, 131, 10011012.

Lindner M, Maroschek M, Netherer S et al. (2010) Climate change impacts, adaptive capacity, and vulnerability of European forest ecosystems. Forest Ecology and Management, 259, 698-709.

Lloret F, Keeling EG, Sala A (2011) Components of tree resilience: effects of successive low-growth episodes in old ponderosa pine forests. Oikos, 120, 1909-1920.

Ma Q, Huang JG, Hanninen H, Berninger F (2019) Divergent trends in the risk of spring frost damage to trees in Europe with recent warming. Global Change Biology, 25, 351-360.

Martin-Benito D, Pederson N, Köse N, Doğan M, Bugmann H, Mosulishvili M, Bigler C (2018) Pervasive effects of drought on tree growth across a wide climatic gradient in the temperate forests of the Caucasus. Global Ecology and Biogeography, 27, 13141325.

McDowell N, Pockman WT, Allen CD et al. (2008) Mechanisms of plant survival and mortality during drought: why do some plants survive while others succumb to drought? New Phytologist, 178, 719-739.

McDowell NG, Beerling DJ, Breshears DD, Fisher RA, Raffa KF, Stitt M (2011) The interdependence of mechanisms underlying climate-driven vegetation mortality. Trends in Ecology \& Evolution, 26, 523-532.

McDowell NG, Michaletz ST, Bennett KE, Solander KC, Xu C, Maxwell RM, Middleton RS (2018) Predicting chronic climate-driven disturbances and their mitigation. Trends in Ecology \& Evolution, 33, 15-27.

Michelot A, Simard S, Rathgeber C, Dufrêne E, Damesin C (2012) Comparing the intraannual wood formation of three European species (Fagus sylvatica, Quercus petraea and Pinus sylvestris) as related to leaf phenology and non-structural carbohydrate dynamics. Tree Physiology, 32, 1033-1045.

Pasho E, Camarero JJ, de Luis M, Vicente-Serrano SM (2012) Factors driving growth responses to drought in Mediterranean forests. European Journal of Forest Research, 131, 1797-1807.

Pederson N, Dyer JM, McEwan RW et al. (2014) The legacy of episodic climatic events in shaping temperate, broadleaf forests. Ecological Monographs, 84, 599-620.

This article is protected by copyright. All rights reserved. 
Peters RL, Klesse S, Fonti P, Frank DC (2017) Contribution of climate vs. larch budmoth outbreaks in regulating biomass accumulation in high-elevation forests. Forest Ecology and Management, 401, 147-158.

Príncipe A, van der Maaten E, van der Maaten-Theunissen M, Struwe T, Wilmking M, Kreyling J (2017) Low resistance but high resilience in growth of a major deciduous forest tree (Fagus sylvatica L.) in response to late spring frost in southern Germany. Trees, 31, 743-751.

R Core Team (2015) $R$ : A language and environment for statistical computing, Vienna, Austria. http://www.R-project.org/, R Foundation for Statistical Computing.

Rogers BM, Solvik K, Hogg EH et al. (2018) Detecting early warning signals of tree mortality in boreal North America using multiscale satellite data. Global Change Biology, 24, 2284-2304.

Ruehr NK, Offermann CA, Gessler A, Winkler JB, Ferrio JP, Buchmann N, Barnard RL (2009) Drought effects on allocation of recent carbon: from beech leaves to soil CO2 efflux. New Phytologist, 184, 950-961.

Ryan MG (2011) Tree responses to drought. Tree Physiology, 31, 237-239.

Sacks WJ, Kucharik CJ (2011) Crop management and phenology trends in the US Corn Belt: Impacts on yields, evapotranspiration and energy balance. Agricultural and Forest Meteorology, 151, 882-894.

Sanginés de Cárcer P, Vitasse Y, Peñuelas J, Jassey VE, Buttler A, Signarbieux C (2018) Vapor-pressure deficit and extreme climatic variables limit tree growth. Global Change Biology, 24, 1108-1122.

Skomarkova MV, Vaganov EA, Mund M, Knohl A, Linke P, Boerner A, Schulze ED (2006) Inter-annual and seasonal variability of radial growth, wood density and carbon isotope ratios in tree rings of beech (Fagus sylvatica) growing in Germany and Italy. Trees-Structure and Function, 20, 571-586.

Smith MD (2011) An ecological perspective on extreme climatic events: a synthetic definition and framework to guide future research. Journal of Ecology, 99, 656-663.

Stott P (2016) How climate change affects extreme weather events. Science, 352, 1517-1518.

Taschler D, Neuner G (2004) Summer frost resistance and freezing patterns measured in situ in leaves of major alpine plant growth forms in relation to their upper distribution boundary. Plant Cell and Environment, 27, 737-746.

Thornthwaite CW (1948) An approach toward a rational classification of climate. Geographical review, 38, 55-94.

Thornton PE, Running SW, White MA (1997) Generating surfaces of daily meteorological variables over large regions of complex terrain. Journal of Hydrology, 190, 214-251.

van der Maaten-Theunissen M, Kahle H-P, van der Maaten E (2012) Drought sensitivity of Norway spruce is higher than that of silver fir along an altitudinal gradient in southwestern Germany. Annals of Forest Science, 70, 185-193.

Vicente-Serrano SM, Beguería S, López-Moreno JI (2010) A multiscalar drought index sensitive to global warming: the standardized precipitation evapotranspiration index. Journal of Climate, 23, 1696-1718.

Vicente-Serrano SM, Camarero JJ, Azorin-Molina C (2014) Diverse responses of forest growth to drought time-scales in the $\mathrm{N}$ orthern $\mathrm{H}$ emisphere. Global Ecology and Biogeography, 23, 1019-1030.

Vitali V, Buntgen U, Bauhus J (2017) Silver fir and Douglas fir are more tolerant to extreme droughts than Norway spruce in south-western Germany. Global Change Biology, 23, 5108-5119.

This article is protected by copyright. All rights reserved. 
Vitali V, Büntgen U, Bauhus J (2018) Seasonality matters-The effects of past and projected seasonal climate change on the growth of native and exotic conifer species in Central Europe. Dendrochronologia, 48, 1-9.

Vitasse Y, Bottero A, Rebetez M, Conedera M, Augustin S, Brang P, Tinner W (2019) What is the potential of silver fir to thrive under warmer and drier climate? European Journal of Forest Research, 138, 547-560.

Vitasse Y, Lenz A, Koerner C (2014) The interaction between freezing tolerance and phenology in temperate deciduous trees. Frontiers in Plant Science, 5, 1-12.

Vitasse Y, Rebetez M (2018) Unprecedented risk of spring frost damage in Switzerland and Germany in 2017. Climatic Change, 149, 233-246.

Vitasse Y, Schneider L, Rixen C, Christen D, Rebetez M (2018a) Increase in the risk of exposure of forest and fruit trees to spring frosts at higher elevations in Switzerland over the last four decades. Agricultural and Forest Meteorology, 248, 60-69.

Vitasse Y, Signarbieux C, Fu YH (2018b) Global warming leads to more uniform spring phenology patterns across elevations. Proceedings of the National Academy of Sciences of the United States of America, 115, 1004-1008.

Vitra A, Lenz A, Vitasse Y (2017) Frost hardening and dehardening potential in temperate trees from winter to budburst. New Phytologist, 216, 113-123.

Weber R, Gessler A, Hoch G (2019) High carbon storage in carbon-limited trees. New Phytologist, 222, 171-182.

Yin J, Bauerle TL (2017) A global analysis of plant recovery performance from water stress. Oikos, 126, 1377-1388.

Zohner CM, Rockinger A, Renner SS (2019) Increased autumn productivity permits temperate trees to compensate for spring frost damage. New Phytologist, 221, 789795.

This article is protected by copyright. All rights reserved. 